DOI: 10.2478/v10014-008-0013-6

Agrovoc descriptors: climatic change; precipitation; rain; erosion; water erosion; top soil; weather hazards; damage; farmland

Agris category code: P40; P36

COBISS code 1.01

\title{
A comparative study of rainfall erosivity for eastern and western Slovenia
}

\author{
Andrej CEGLAR ${ }^{1}$, Zalika ČREPINŠEK ${ }^{2}$, Vesna ZUPANC ${ }^{3}$, Lučka KAJFEŽ- \\ BOGATAJ $^{4}$
}

Received June 26, 2008; accepted August 1, 2008.

Delo je prispelo 26. junija 2008; sprejeto 1.avgusta 2008.

\section{ABSTRACT}

Climate in Slovenia has changed notably over the past century. As regional temperatures have risen, a more vigorous hydrologic cycle ensued; in many places the intensity of rainstorms has become greater. The seasonal distributions of rainfall has changed with significant implications for patterns of vegetation growth and hence for soil erosion. Due to predicted climate change increased frequency of extreme precipitation events can be expected during the time when soil is without plant cover and exposed to the erosive forces. In addition to ample daily and several day precipitation events, water erosion occurs with heavy rainfalls that last from couple of minutes to several hours. Overview of rainfall intensity index and rainfall erosivity, calculated with adapted USLE (universal soil loss equation) method, is given for three meteorological stations in Slovenia for period 1991-2006. Analyzed locations are situated on different climate areas with noticeable different rainfall regime at western (Bilje at Nova Gorica, Rateče) and eastern (Murska Sobota) part of Slovenia.

Key words: rainfall intensity, rainfall erosivity, soil water erosion, Slovenia

\section{IZVLEČEK}

\section{PRIMERJAVA EROZIVNOSTI PADAVIN V ZAHODNI IN VZHODNI SLOVENIJI}

Meritve dokazujejo, da erozija na kmetijskih zemljiščih nikakor ni zanemarljiva in je najintenzivnejša na njivskih površinah. Podnebje se je $v$ Sloveniji že spremenilo, temperature zraka in tal naraščajo, spreminja pa se tudi vodni cikel. Opažamo sezonsko preporazdelitev padavin, daljše in intenzivnejše poletne suše, pa tudi naraščanje intenzivnosti nalivov, kar vse močno vpliva na erozijske procese. Zaradi predvidenih klimatskih sprememb lahko pričakujemo povečano pogostost in intenziteto ekstremnih padavin $v$ času, ko so tla brez rastlinskega

Assistant., B.Sc.Met., University of Ljubljana, Biotechnical Faculty, Department of Agronomy, p.p. 2995, SI-1001, Ljubljana, Slovenia, andrej.ceglar@bf.uni-lj.si

Assistant Prof., Ph. D., ibid

Assistant, Ph. D., ibid

4 Prof., Ph. D., ibid 
pokrova in izpostavljena erozivnim silam. Poleg obilnih dnevnih in večdnevnih padavin povzročajo vodno erozijo tudi nalivi, ki trajajo od nekaj minut do nekaj ur. Za tri meteorološke postaje (Bilje pri Novi Gorici, Murska Sobota in Rateče), ki so na klimatsko različnih območjih Slovenije, je za obdobje 1991-2006 podan pregled ekstremnih količin padavin v različnih časovnih intervalih, indeks intenzitete dnevnih padavin ter erozivnost padavin, izračunana po prirejeni metodi univerzalne enačbe izgube tal (USLE).

Ključne besede: intenziteta padavin, erozivnost padavin, vodna erozija tal, Slovenija

\section{$1 \quad$ INTRODUCTION}

Soil erosion is a natural process that can be accelerated dramatically following improper land use and/or management. Human activities can result in erosion rates that are many times greater than natural rates. World-wide, erosion is considered to be the most widespread and serious form of soil degradation (Mabit and Bernard, 2007). With the decrease of agricultural land use in Slovenia due to natural, social and economic factors, the amount of material lost to erosion has decreased in the last few decades. However, field measurements proved that erosion on agricultural land is by no means negligible and is most intensive on cultivated fields (Komac and Zorn, 2005). Since this category of land use is constantly decreasing due to abandonment of agricultural practice, the existent agricultural areas and prevention measures against soil degradation are of utmost importance.

Climate in Slovenia has changed during last decades, air and soil temperatures have increased significantly, and water cycle is altering (Bergant et al., 2002; Bergant and Kajfež-Bogataj, 2005). Rearrangement of precipitation patterns, more vigorous and frequent long-duration droughts and rise of rainfall intensity, that influence noticeable erosion processes, are noticed recently. Average annually relative variability of precipitation is high in all climatic regions. There have been no significant changes in the amount of precipitation in last decades in Slovenia, but the greater intensity of showers and a lower number of days with snow cover were found. Precipitation regime within seasons has also changed; precipitation maximum in autumn is more expressive (ARSO, 2006). Regional scenarios of future climate change predict more intensive precipitation in a changed precipitation regime, more frequent and intense extreme weather events such as droughts, floods and thunderstorms during the time when soil is without plant cover and exposed more to the erosive forces (Kajfež-Bogataj and Bergant, 2005).

The study of mechanisms of water erosion brings out two characteristics of precipitation, which make it the dominating causative factor of the phenomenon: intensity and depth of amount (which depends on the intensity-duration combination) (WMO, 1983). Hudson (1995) defined three attributes of rain pertaining to erosion. Intensity of a rain, generally expressed as $\mathrm{mm} / \mathrm{h}$, is usually highly variable during the course of a rainstorm. The time-pattern of rain intensity also differs from storm to storm, from place to place and from season to season. The second attribute is the duration of a rain, the length of time from the start of a rainstorm to its ending. This is often arbitrarily determined due to alternating periods of stronger and weaker rain intensity of rainstorm events. According to Kolbezen 
(1979), rainfall with intensity exceeding $40 \mathrm{~mm}$ /day can cause erosion. As the third parameter Hudson (1995) states the energy of a rainstorm, being the summation of the kinetic energies of all raindrops falling on a unit area. Direct measurements of the kinetic energy are possible (Hillel, 1998), but not very common. Rainfall intensity is parameter measured on standard meteorological stations and data are easily available.

Rainfall kinetic energy $(E)$ in particular has often been suggested as an indicator of rainfall erosivity, i.e. ability of rainfall to detach soil particles (van Dijk et al., 2002). Wischmeier and Smith (1978) used in their empirical model of Universal Soil Loss Equation (USLE) rainfall erosivity $R$ for estimation of rainfall capability to cause the soil loss. $R$ customarily represents the average annual accumulated storm erosivity index (EI) (Lal, 1994). EI is calculated with method, that includes the sum of kinetic energy of individual storm and it is multiplied with the maximum precipitation amount in any given $30 \mathrm{~min}$ interval of a storm. The erosive power of the rain is statistically best related to the total storm energy multiplied by the maximum 30 minute storm intensity (Wischmeier, 1959). EI represents the combined effect of direct measurements; raindrop impact and surface flow for rainfall induced soil erosion (Römkens et al., 2002). Mikoš et al. (2006) used RUSLE (Revised Universal Soil Loss Equation) to estimate the EI for the Alpine climate of north Slovenia. The RUSLE method for EI computation was also used by Zorn and Petan (2007) in measurements of interrill soil erosion under different land use in Slovenian Istria. The purpose of this study was to determine the seasonal variability of kinetic energy of rainfall using measured rainfall rates and intensities for three different climatic regions of Slovenia.

\section{MATERIAL AND METHODS}

Precipitation data (ARSO, 2007) measured in various time intervals (breakpoints) for the 1991 2006 period were analyzed for meteorological stations Bilje at Nova Gorica, Murska Sobota and Rateče, representing three different climatic regions (mediterranean, continental and alpine) in Slovenia. Meteorological definition of seasons was applied: winter from December to February, spring from March to May, summer from June to August and autumn from September to November.

\subsection{Rainfall intensity index}

Rainfall intensity index $(I)$ was calculated as a relationship between rainfall amount and number of days with rainfall in a certain period $(\mathrm{mm} / \mathrm{h})$, calculated values were compared considering average values of the index for the $1961-1990$.

\subsection{Number of days with rainfall amount exceeding $40 \mathrm{~mm}$}

For the considered period we determined number of days with rainfall amount higher than $40 \mathrm{~mm}$.

\subsection{Rainfall erosivity}

Rainfall erosivity of 30 min rainfall events $\left(E I_{30}\right)$ was calculated using method by Wischmeier and Smith (1978) as

$$
E I_{30}=E \cdot I_{30}
$$


where $I_{30}$ is the maximum 30 min rainfall intensity index, $E$ is rainfall kinetic energy $(\mathrm{MJ} / \mathrm{ha})$, calculated after Brown and Foster (1987) and Yin et al. (2007) as

$E=\sum_{r=1}^{k} 0,29\left[1-0,72 \cdot \exp \left(-0,05 i_{r}\right)\right]\left(\Delta V_{r}\right)$

where each storm is divided into $k$ parts, $k$-part representing the breakpoint resolution of the pluviograph resolution, which is $5 \mathrm{~min}$ in Slovenia (ARSO, 2007), $i_{r}(\mathrm{~mm} / \mathrm{h})$ is rainfall intensity for the $r$-th part of the storm, $\Delta V_{r}(\mathrm{~mm})$ is the rainfall depth for the $r$-th part of the storm and $l_{30}$ is the maximum 30 min rainfall intensity index. It is calculated as:

$I_{30}=\frac{P_{30}}{0,5 h}$

where $P_{30}$ is the maximum 30 min rainfall depth (Yin et al., 2007).

Storm is defined arbitrarily as one rainfall event separated from another rainfall event by more than six hours with less than $1 \mathrm{~mm}$ of rain (Lal, 1994) with intensity higher than $1.25 \mathrm{~mm} / \mathrm{h}$ (Römkens et al., 2002). Storms with less than $13 \mathrm{~mm}$ of rain generally do not cause appreciable soil loss, defined as greater than or equal to $0.02 \mathrm{t} / \mathrm{ha}$. However, short, intense bursts of rainfal less than $13 \mathrm{~mm}$ often exceed the infiltration rate of a plot soil and cause measurable soil loss. Therefore rains of less than $13 \mathrm{~mm}$ but with a $15 \mathrm{~min}$ intensity of $25 \mathrm{~mm} / \mathrm{h}$ or greater are included (Lal, 1994) in calculation. Monthly rainfall erosivity $\left(E I_{m}\right)$, which was the average of all computed $\mathrm{El}_{30}$ values over a certain month, was calculated after Shamshad et al. (2008) as

$E I_{m}=\frac{1}{n} \sum_{j=1}^{n}\left[\sum_{k=1}^{m}\left(E \cdot I_{30}\right)_{k}\right]$

where $j$ is the index for the number of years used to compute the average, $k$ is the index of the number of storms in each year, $n$ is the number of years to obtain average $E l$, and $m$ is the number of storms in each year.

\section{$3 \quad$ RESULTS}

\subsection{Number of days with rainfall amount over $40 \mathrm{~mm}$}

Table 1 and Figure 1 show number of days with rainfall amount exceeding $40 \mathrm{~mm}$. Daily rainfall amounts over $40 \mathrm{~mm}$ were most frequent in the autumn at all discussing meteorological stations; the number of such days was the highest in Rateče. Number of days with intense rainfall is significantly smaller in Murska Sobota compared to the other two rain gauge stations. For northeast Slovenia it is a general rule that extreme rainfall events are extremely rare. Extreme rainfall occurs between longer lasting storms or if there are several consecutive storms in the period of one measurement. In the studied 16 years period we measured $1-2$ days with rainfall over $40 \mathrm{~mm}$ in Murska Sobota, whereas in Rateče and Bilje over $10 \mathrm{such}$ days were measured annually. 
CEGLAR, A. in sod.: A comparative study of rainfall erosivity for eastern and western ...335

Table 1: Number of days with rainfall amount over $40 \mathrm{~mm}$ for Bilje, Rateče and Murska Sobota (1991-2006).

\begin{tabular}{|c|c|c|c|c|c|c|c|c|c|c|c|c|}
\hline Year & Bilje & \multicolumn{1}{|l|}{ Rateče } & \multicolumn{4}{|c|}{ Murska Sobota } \\
\hline & Win & Spr & Sum & Aut & Win & Spr & Sum & Aut & Win & Spr & Sum & Aut \\
\hline 1991 & 0 & 1 & 3 & 6 & 0 & 2 & 2 & 5 & 0 & 0 & 2 & 0 \\
\hline 1992 & 2 & 3 & 2 & 5 & 2 & 2 & 0 & 4 & 0 & 0 & 0 & 2 \\
\hline 1993 & 3 & 0 & 0 & 9 & 2 & 3 & 1 & 7 & 0 & 0 & 0 & 0 \\
\hline 1994 & 2 & 3 & 0 & 3 & 0 & 2 & 1 & 2 & 1 & 0 & 1 & 1 \\
\hline 1995 & 3 & 3 & 4 & 2 & 2 & 0 & 1 & 2 & 0 & 1 & 1 & 1 \\
\hline 1996 & 3 & 3 & 2 & 4 & 0 & 4 & 4 & 8 & 0 & 0 & 1 & 1 \\
\hline 1997 & 2 & 1 & 4 & 4 & 0 & 1 & 0 & 3 & 0 & 0 & 1 & 0 \\
\hline 1998 & 1 & 2 & 4 & 10 & 0 & 3 & 1 & 9 & 0 & 0 & 1 & 4 \\
\hline 1999 & 0 & 1 & 0 & 1 & 0 & 3 & 3 & 5 & 1 & 0 & 0 & 0 \\
\hline 2000 & 1 & 3 & 2 & 9 & 0 & 2 & 2 & 11 & 0 & 0 & 0 & 0 \\
\hline 2001 & 0 & 1 & 1 & 2 & 0 & 4 & 1 & 2 & 0 & 0 & 0 & 0 \\
\hline 2002 & 1 & 0 & 6 & 3 & 0 & 2 & 1 & 6 & 0 & 0 & 0 & 0 \\
\hline 2003 & 6 & 0 & 0 & 4 & 1 & 6 & 4 & 5 & 0 & 0 & 0 & 0 \\
\hline 2004 & 1 & 0 & 1 & 5 & 1 & 7 & 2 & 4 & 0 & 0 & 1 & 0 \\
\hline 2005 & 2 & 1 & 2 & 4 & 0 & 2 & 1 & 2 & 0 & 0 & 2 & 0 \\
\hline 2006 & 2 & 1 & 1 & 1 & 2 & 1 & 1 & 2 & 0 & 0 & 2 & 0 \\
\hline
\end{tabular}

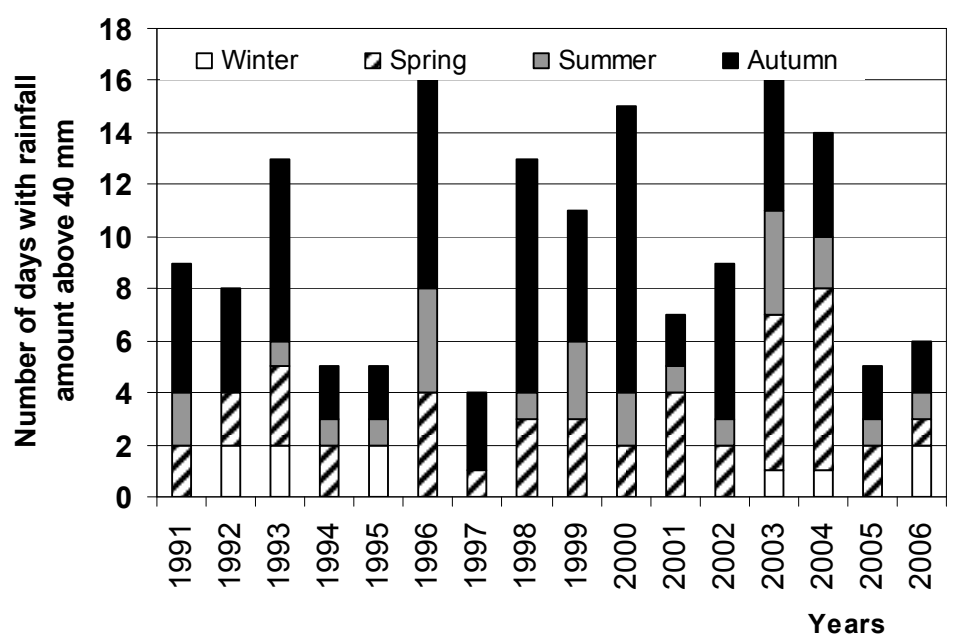

Figure 1: Number of days with rainfall amount over $40 \mathrm{~mm}$ for Rateče (1991 2006).

\subsection{Rainfall Intensity Index}

Rainfall intensity index and rainfall amount for spring and autumn in Rateče are shown on Figures 2a and 2b. Average spring rainfall amount was $377 \mathrm{~mm}$ for 19611990 and only $291 \mathrm{~mm}$ for 1991-2006, trend is significantly negative. Rainfall intensity index for spring also shows negative trend, which indicates less raining days. Maximum rainfall amount was measured during spring $1975(760 \mathrm{~mm})$, and maximum rainfall intensity index in 1962, when average rainy day had about $20 \mathrm{~mm}$ of rainfall. For Rateče maximum number of raining day was 42 in spring 1975 and 
minimum number of raining days (17) was measured during spring 2003, which shows also the highest difference between rainfall amount and rainfall intensity index.

a)

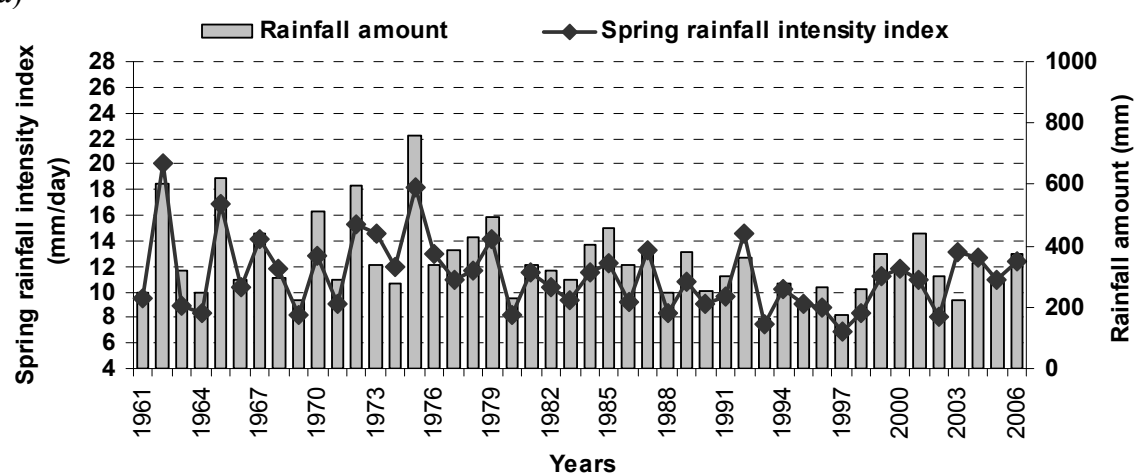

b)

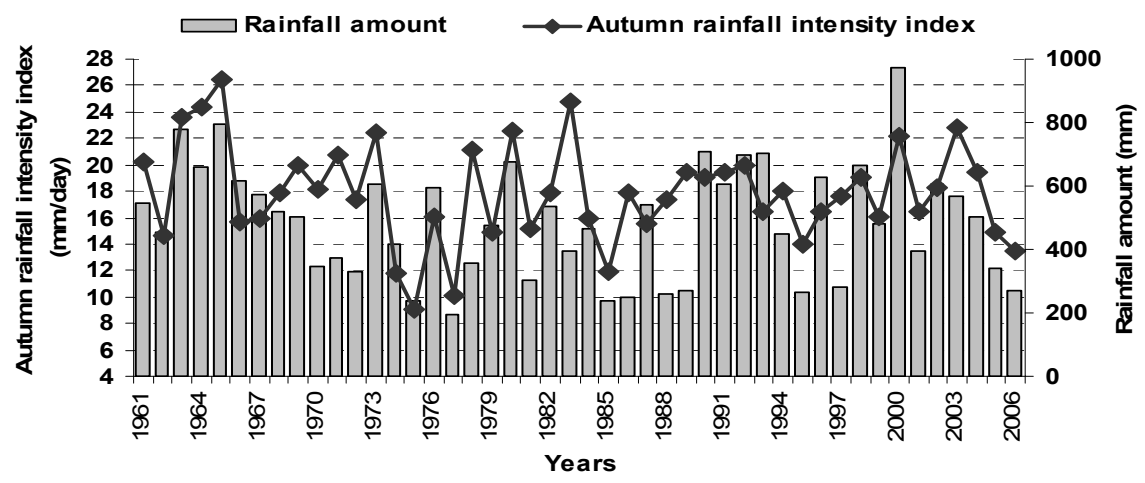

Figure 2: Rainfall intensity index and rainfall amount for spring (Fig. a) and autumn (Fig. b) for Rateče (1961-2006).

Average spring rainfall amount showed negative trend also in Bilje, but this is not the case for Murska Sobota (Fig. 3a, b; Fig. 4a, b). The wettest period in Rateče is autumn that is why rainfall intensity is correspondingly higher than in spring. Average autumn rainfall amount was $467 \mathrm{~mm}$ for 1961-1990 and $527 \mathrm{~mm}$ for 19912006 in Rateče, where the trends in the autumn rainfall amount and daily rainfall intensity are significantly positive $(\alpha=0.05)$. The wettest autumn was noticed in 2000 with 44 raining days, and the maximum rainfall intensity in 1965, when $800 \mathrm{~mm}$ of rainfall was measured in 30 raining days. The trends in the autumn rainfall amount are significantly positive also in Bilje and Murska Sobota. 
a)

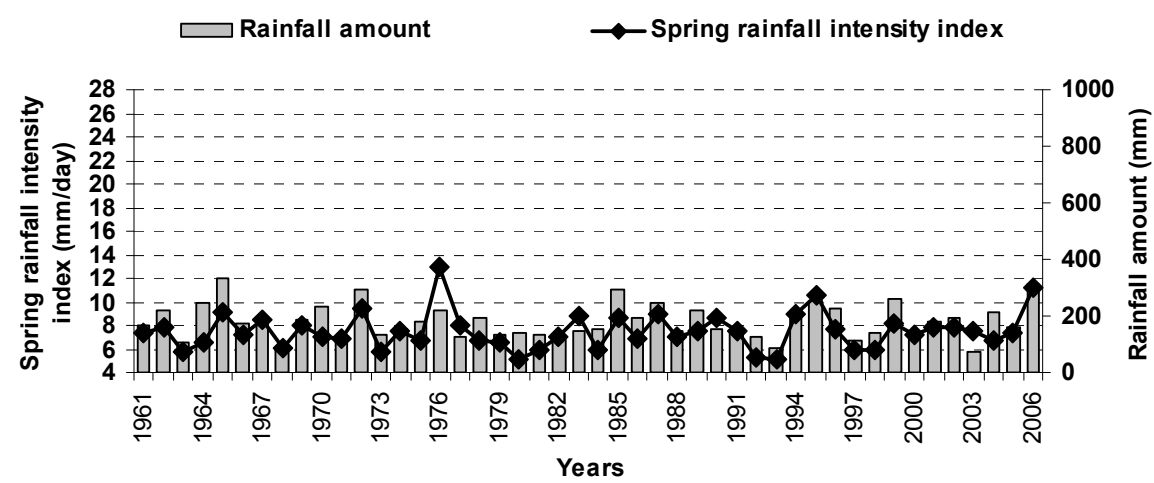

b)

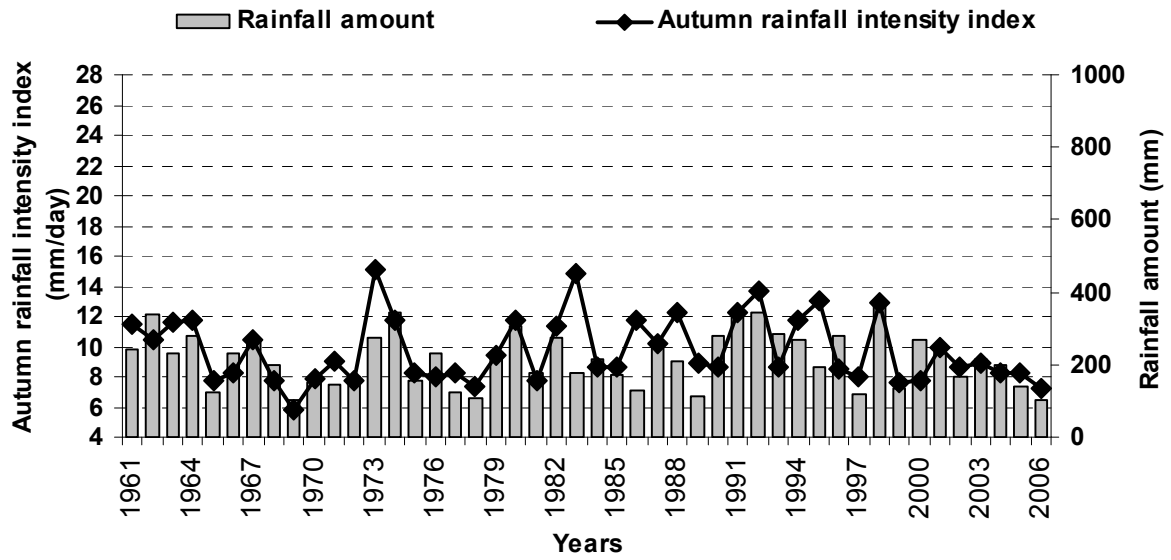

Figure 3: Rainfall intensity index and rainfall amount for spring (Fig. a) and autumn (Fig. b) for Murska Sobota (1961-2006). 
a)

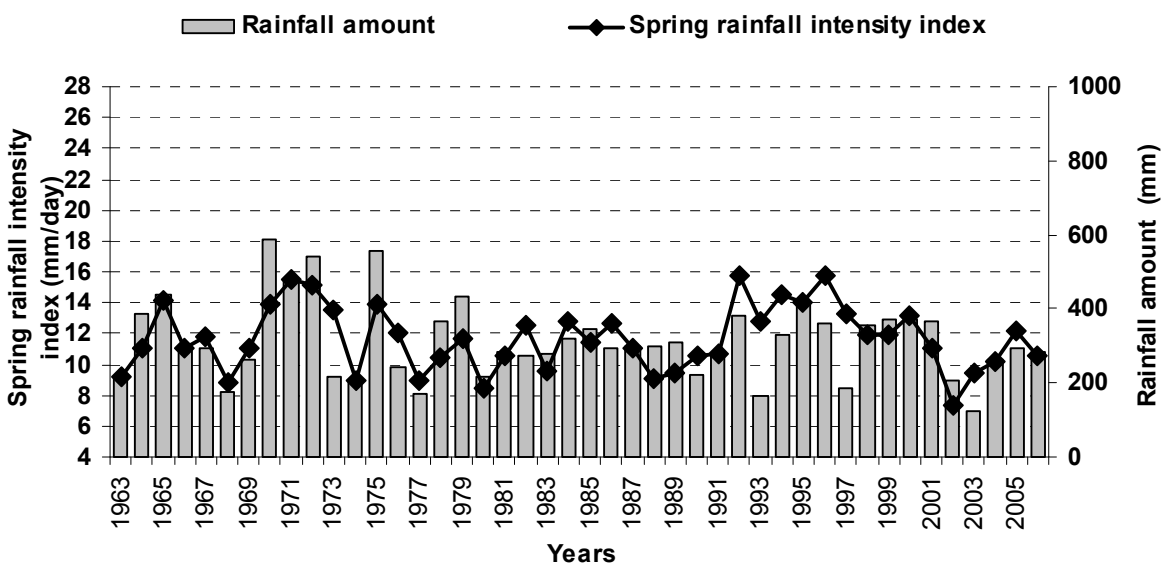

b)

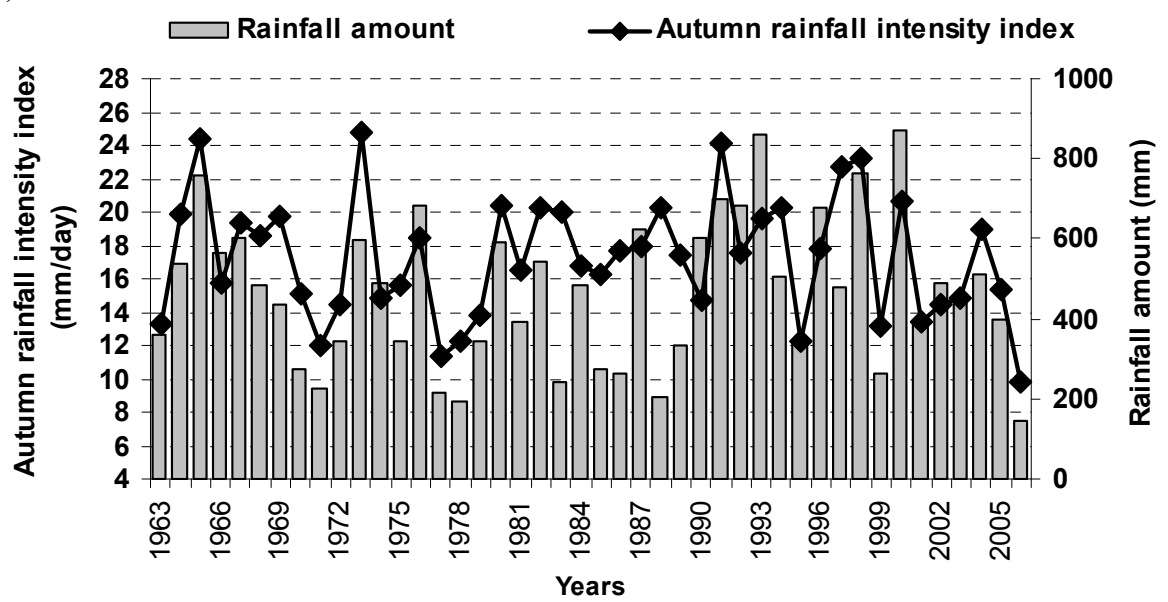

Figure 4: Rainfall intensity index and rainfall amount for spring (Fig. a) and autumn (Fig. b) for Bilje (1963-2006).

\subsection{Rainfall erosivity}

Monthly rainfall erosivity $\left(E I_{\mathrm{m}}\right)$ (eq. 4) for discussing stations is shown on the Figure 5. Winter months were not considered, as $E I_{\mathrm{m}}$ values for winter months are not reliable enough because snowfall causes higher error probability of the precipitation measurements. In the considered period, the highest $E I_{\mathrm{m}}$ was calculated for the rainfall station Bilje, where values from April to November exceed $100 \mathrm{MJ} \cdot \mathrm{ha} \mathrm{m}^{-1} \mathrm{~mm} \cdot \mathrm{h}^{-1}$. Ramos and Martinez-Casasnovas (2006) quoted that 28$55 \%$ of rainfall amount is lost owing to surface flow at EI more than $140 \mathrm{MJ} \cdot \mathrm{ha^{-1 }} \mathrm{mm} \cdot \mathrm{h}^{-1}$, depending on characteristics of rainfall events. The highest deviation is estimated for September at Bilje $\left(1280 \mathrm{MJ} \cdot h a^{-1} \mathrm{~mm} \cdot \mathrm{h}^{-1}\right)$. This high value was caused by a storm event on 14.9.1997, when rainfall amount 
exceeded $50 \mathrm{~mm}$ in 30 minutes. At Murska Sobota and Rateče month with the

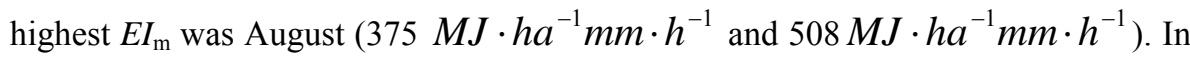
early spring the rainfall erosivity is relatively low on all three stations. Zorn and Petan (2007) stated that a week in August 2005 with weekly EI of $1235.91 \mathrm{MJ} \cdot \mathrm{ha^{-1 }} \mathrm{mm} \cdot \mathrm{h}^{-1}$ contributed to $30 \%$ of annually eroded material from olive orchard in maritime Slovenia, whereas in 2006 a storm event with EI of

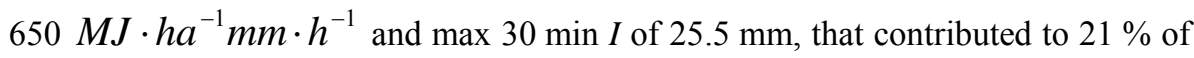
annual erosion on a field and $52 \%$ on an overgrowing meadow, was measured.

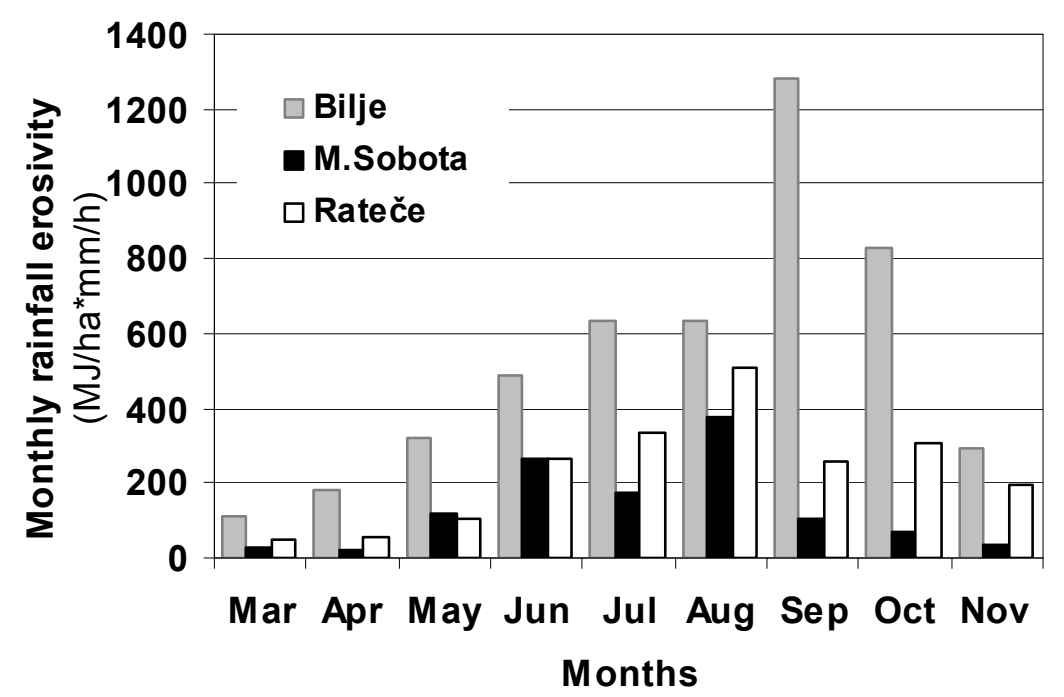

Figure 5: Monthly rainfall erosivity $\left(E I_{\mathrm{m}}\right)$ for Bilje, Murska Sobota and Rateče (1991-2006).

4

\section{CONCLUSIONS}

Extreme precipitation events are frequent in North-western Slovenia and extremely rare in North-eastern part, where extreme amounts of precipitation occur during longer lasting heavy storms or if there are several consecutive storms in the period of one measurement. Discussing agricultural areas are the most vulnerable in autumn, when number of days with rainfall amount exceeding $40 \mathrm{~mm}$ is the highest. This holds especially for Bilje, which has the highest $E I_{30}$ in September and October. Monthly rainfall erosivity for Murska Sobota and Rateče was highest at the end of summer (August). Because of erosion, we lose yearly $5-10 \mathrm{~mm}$ of fertile agricultural soils (Mikoš and Zupanc, 2000), that amount loss to $80-100 \mathrm{t} / \mathrm{ha} /$ year. Due to predicted climate change increased frequency of extreme events can be expected, amongst also extreme precipitation events (Kajfež-Bogataj and Sušnik, 2007). Zorn and Petan (2007) showed that extreme events contribute to significant proportions of annual soil loss, which means that soil vulnerability to soil water erosion is likely to increase as well. 
Rainfall intensity has increased recently at many locations in Slovenia (Sušnik et al., 2006). In spite of the fact, that direct measurements of soil erosion in Slovenia are very rare (Komac and Zorn, 2005; Suhadolc et al., 2006), agricultural practice shows that farmers are already forced to adapt to local conditions and that they are using different methods for prevention or reduction of soil erosion (selection of appropriate crops, grassing, no tillage, soil cultivation parallel with height contours, terracing, application of appropriate agricultural mechanisation, etc.). Erosion phenomena in Slovenia extend over $9000 \mathrm{~km}^{2}$ or $44 \%$ of the country's territory, mostly water erosion (Suhadolc et al., 2006). Soil is essentially a non-renewable resource with extremely slow formation and regeneration processes. Soil degradation rates can be potentially rapid and conditions are aggravated by climate change, therefore prevention, precaution and sustainable soil management should be at the core of soil protection policies.

\section{LITERATURE}

ARSO, 2006. Climate conditions in Slovenia for the period 1971-2000. Environmental Agency of the Republic of Slovenia. Ljubljana, $28 \mathrm{p}$.

ARSO, 2007. Meteorological archives of Environmental Agency of the Republic of Slovenia. Data for the period 1961-2006. Ljubljana, (extract from archives).

Bergant, K., Kajfež-Bogataj, L., Črepinšek, Z. 2002. Statistical downscaling of generalcirculation-model- simulated average monthly air temperature to the beginning of flowering of dandelion (Taraxacum officinale) in Slovenia. Int. J. Biomet., 46: 22-32.

Bergant, K., Kajfež-Bogataj, L. 2005. N-PLS regression as empirical downscaling tool in climate change studies. Theor. Appl. Climatol., 1-2, 81: 11-23.

Brown, L.C., Foster, G.R. 1987. Storm erosivity using idealized intensity distributions. Trans. ASAE 30: 379-386.

Hillel, D. 1998. Environmental Soil Pysics. Academic Press, 771 pp.

Hudson, N. 1995. Soil Conservation, $3^{\text {rd }}$ Edition, Batsford Book, London, 391 pp.

Kajfež-Bogataj, L., Bergant, K. 2005. What might the climate of Slovenia look like in this century? Ujma (Ljubljana), 19: 218-223.

Kajfež-Bogataj, L., Sušnik, A. 2007. Challenges to agrometeorological risk management regional perspectives: Europe. In: SIVAKUMAR, Mannava V.K. (Ed.), MOTHA, Raymond P. (Ed.). Managing weather and climate risks in agriculture. Springer Verlag; Berlin; Heildelberg; New York, 114-124.

Kolbezen, M. 1979. Transport hribinskega materiala na potokih vzhodnega in jugovzhodnega Pohorja kot posledica erozije tal. Ljubljana, Geografski vestnik 51: 73:83 (In Slovenian).

Komac, B., Zorn, M. 2005. Erozija prsti na kmetjskih zemljiščih v Sloveniji - Meritve žlebične erozije v dolini Besnice. Acta geographica Slovenica. 45-1: 53-86 (In Slovenian).

Lal, R. 1994. Soil Erosion Research Methods (Ed.). 2nd Edition. Soil and Water Conservation Society, Ankeny, 340 pp. 
CEGLAR, A. in sod.: A comparative study of rainfall erosivity for eastern and western ...341

Mabit, L., Bernard, C. 2007. Assessment of spatial distribution of fallout radionuclides through geostatistics concept. Journal of Environmental Radioactivity, 97, 2-3: 206-219.

Ramos, M.C., Martínez-Casasnovas, J.A. 2006. Nutrient losses by runoff in vineyards of the Mediterranean Alt Penedès region (NE Spain). Agriculture, Ecosystems \& Environment, 13, 1-4: 356-363.

Mikoš, M., Jošt, D., Petkovšek, G. 2006. Rainfall and runoff erosivity in the alpine climate of north Slovenia: a comparison of different estimation methods. Hydrol. Sci. J., 51: 115-126.

Mikoš, M., Zupanc, V. 2000. Erozija tal na kmetijskih površinah. Sodobno kmetijstvo, 33, 10: 419-423 (In Slovenian).

Römkens, M.J.M., Dabney, S.M., Govers, G., Bradford, J.M. 2002. Soil Erosion by Water and Tillage. In: Dane, J.H., Topp, C.G. (Ed.) Methods of Soil Analysis, 4: Physical Methods. Soil Sci. Soc. Am. Inc., Madison, Wisconsin, USA, 16211662.

Shamshad, A., Azhari, M.N., Isa, M.H., Wan Hussin, W.M.A., Parida, B.P. 2008. Development of an appropriate procedure for estimation of RUSLE EI30 index and preparation of erosivity maps for Pulau Penang in Peninsular Malaysia. Catena, 72, 3, 31: 423-432.

Suhadolc, M., Lobnik, F., Turk, I. 2006. Assessment of implementation of UN Convention to combat desertification/land degradation in Slovenia. Ljubljana, The Regional Environmental Center for Central and Eastern Europe, 64 pp.

Sušnik, A., Kajfež-Bogataj, L., Bergant, K., Cegnar, T., Črepinšek, Z., Gregorič, G., Rogelj, D., Žust, A. 2006. Climate change: it is not too late if farmers act now. Ljubljana, Environmental Agency of the Republic of Slovenia, $40 \mathrm{pp}$.

Van Dijk, A.I.J.M., Bruijnzeel, L.A., Rosewell, C.J. 2002. Rainfall intensity-kinetic energy relationships: a critical literature appraisal. Journal of Hydrology, 261:1-23.

Yin, S., Xie, Y., Nearing, M.A., Wang, C. 2007. Estimation of rainfall erosivity using 5- to 60-minute fixed-interval rainfall data from China. Catena., 70, 3: 306-312.

Wischmeier, W.H. 1959. A rainfall erosion index for a universal soil loss equation. Soil Sci. Soc. Am. Proc. 23:322-326.

Wischmeier, W.H., Smith, D.D. 1978. Predicting rainfall erosion losses. Agricultural Handbook 537, USDA, Washington, 58 pp.

WMO Technical Note No. 178. 1983. Meteorological Aspects of Certain Processes Affecting Soil Degradation - Especially Erosion. Report of the CAgM Working Group on Meteorological Factors Associated with Certain Aspects of Soil Degradation and Erosion. WMO No. 591, 149 pp.

Zorn, M., Petan, S. 2007. Measurement of interrill soil erosion under different land use in Slovene Istria. In: Knapič, M. (Ed.). Strategija varovanja tal v Sloveniji: zbornik referatov Konference ob svetovnem dnevu tal 5. decembra 2007. Ljubljana, Pedološko društvo Slovenije, 51-61 (In Slovenian).

Žagar, T., Kajfež-Bogataj, L., Črepinšek, Z. 2006. Change-point analysis of some climate variables in Slovenia. Acta agric. Slov., 87, 2: 285-298. 